\title{
Health Literacy Requires Empowerment - Results of an Analysis of Patient Needs and the Demand for Qualification over a 10-Year Period
}

Gesundheitskompetenz setzt Befähigung voraus - Ergebnisse einer Analyse zu patientinnenseitigen Bedarfen und Nachfrage nach Qualifizierung über 10 Jahre

Authors

Affiliation

\section{E. Simoes, D. Wallwiener, H. Kusicka, S. Brucker}

Forschungsinstitut für Frauengesundheit, Universitätsfrauenklinik Tübingen, Tübingen

\section{Key words \\ - gynaecology \\ - health literacy \\ - Women's Academy \\ outreach}

Schlüsselwörter

- Frauenheilkunde

- Gesundheitkompetenz

- Frauenakademie

- Reach-out

Deutschsprachige Zusatzinformationen online abrufbar unter: www.thieme-connect.de/ ejournals/toc/gebfra

\section{received $\quad 6.8 .2013$ \\ revised 24.9.2013 \\ accepted 24.9.2013}

\section{Bibliography}

DOI http://dx.doi.org/

10.1055/s-0033-1350982

Geburtsh Frauenheilk 2013; 73:

1023-1027 @ Georg Thieme

Verlag KG Stuttgart · New York .

ISSN 0016-5751

\section{Correspondence}

\section{Prof. Elisabeth Simoes,}

Dr. med.

Universitätsfrauenklinik

Tübingen

Forschungsinstitut

für Frauengesundheit

Calwerstraße 7

72076 Tübingen

simoes@t-online.de

\section{Abstract \\ $\nabla$}

Patients are expected to be increasingly competent about health issues, and patient self-determination is on the rise. This makes it ever more necessary to provide high quality information which is increasingly being offered to patients at all levels of the healthcare system. One example of a regionally available information service offered to patients is the Women's Academy, created 10 years ago, at the University Women's Hospital Tübingen in association with the Institute for Women's Health. The Women's Academy also serves as a forum and an outreach hub for the (cancer) centres of the Women's Hospital. The topics addressed include problematic areas in medicine and problems in coping with health and disease and additionally reflect the emergence of various patient interests and needs over time. The communication between physician and patient is central to the promotion of health literacy and individualised medicine. Regionally available services like the Women's Academy offer complementary benefits and are able to reach vulnerable groups of women who have little or no access to online information.

\section{Zusammenfassung \\ $\nabla$}

Der Bedarf an qualitativ hochstehender Information für die zur Mitentscheidung aufgerufene Patientin erhöht sich in dem Maß, wie die Anforderungen an Kompetenz und Selbstbestimmung in Gesundheitsfragen zunehmen. Befähigung zu mündigen Entscheidungen seitens der Patient/innen zählt zu den alltäglichen Aufgaben von Frauenärzt/innen. Erweiterte Anforderungen dafür ergeben sich aus der Variabilität des Qualifizierungsbedarfs vor dem Hintergrund wechselnder Bedingungen, z.B. durch neue Möglichkeiten genetischer Diagnostik, aus versicherungsrechtlichen Implikationen und Konsequenzen der Nocebo-Forschung. Besondere Ressourcen hierfür stehen in den Vergütungssystemen nicht zur Verfügung. Es besteht Bedarf an ergänzenden Wegen zur Förderung von Gesundheitsmündigkeit. (Inter-)national werden auf allen Ebenen der Gesundheitssysteme Angebote zunehmend bereitgestellt. Beispiel für ein regional ausgerichtetes Angebot ist die seit 10 Jahren bestehende Frauenakademie an der Universitätsfrauenklinik Tübingen im Verbund mit dem Forschungsinstitut für Frauengesundheit. Die Frauenakademie dient als Forum und als Reach-out-Element für die an der Frauenklinik wirkenden Organ(krebs)zentren. In den Themen spiegeln sich Problemzonen der Medizin, des Umgangs mit Gesundheit und Krankheit sowie im Rückblick die Entwicklung der patientinnenseitigen Interessen und Bedarfe. Die Arzt-Patienten-Kommunikation steht im Mittelpunkt der Vermittlung von Gesundheitskompetenz und der individualisierten Medizin. Regionale Angebote wie die Frauenakademie wirken ergänzend und erreichen u.a. auch vulnerable Gruppen von Frauen, für die internetgebundene Information schwer oder nicht zugänglich ist. 


\section{Introduction}

\section{$\nabla$}

Changes in recent years have increasingly focused on the need for self-determination by responsible citizens, and promoted greater levels of patient self-determination in health issues. These changes include co-decision-making in treatment procedures (e.g. informed consent/prepared consent), consensual improvements to the healthcare system (e.g. National Cancer Plan) and a greater emphasis on women's self-determination in the wording of the Cancer Plan Implementation Law, which expressly gives priority to patient self-determination over concerns such as high participation rates in screening programmes and completeness of data (e.g. records in the Cancer Registry) [1]. This has meant that more information must be made available to citizens/patients who are now expected to participate in decisionmaking, and this information must be both of high quality and comprehensible, so that it will sufficiently qualify the patient to allow her to take a responsible decision for herself. At the same time, the available information should be tailored to the patient's personal requirements.

That said, this paper reflects on the importance of these developments, summarises different approaches used for the transfer of information and presents the results and experiences obtained using a special approach: the Women's Academy, an institution set up at the University Women's Hospital Tübingen together with the Institute for Women's Health.

\section{Background: The Ottawa Charter (1986)}

Health and illness/disease are terms which are frequently used in many different areas of life; they leave much room for definition, personal understanding, attribution and interpretation. Book V of the German Social Welfare Code, which deals with statutory health insurance within the scope of German social security legislation, does not include a definition of the terms "health" or "illness" in the true sense of the words. It only describes illness in terms of a process, as a condition which requires medical treatment and/or is the cause of an incapacity to work. A description taken from a judgement by the Federal Social Court of Germany (BSG, 20.10.1972, AZ B3 RK 92/71) is often cited here. In the judgement, illness is referred to as an anomalous physical and mental condition which deviates from the norm, a norm which is informed by the concept of a healthy person. This means that illness is defined indirectly via a model of a "healthy person" for which, in turn, a positive definition is again lacking. All that is left is to take recourse to the definition given by the World Health Organisation (WHO). The WHO included the following definition of health in the Preamble to its Constitution adopted on July 22, 1946: "Health is a state of complete physical, mental and social well-being and not merely the absence of disease or infirmity. The enjoyment of the highest attainable standard of health is one of the fundamental rights of every human being without distinction of race, religion, political belief, economic or social condition." The promotion of this comprehensive definition of health is thus the final goal of all medical activity. But this definition is again multi-faceted. It was therefore only logical that the Ottawa Charter especially emphasised the individual's personal assessment. In this Charter of the 1st International Conference on Health Promotion, health promotion in the WHO model of health is formulated as follows: "Health promotion is the process of enabling people to increase control over, and to improve, their health". This, in turn, requires physicians to empower and enable patients to undertake this "personal definition".

Since then, this guiding principle of the Ottawa Charter has manifested itself in various activities promoting healthcare, for example in the National Cancer Plan (to cite a discursive approach) or the German Cancer Plan Implementation Law which became effective at the beginning of the year (to cite a normative legislative approach) or elsewhere, for example in the guidelines of the German Federal Joint Committee on medical care during pregnancy and after delivery ("Maternity Directives"), in which the prenatal care offered to pregnant women is part of health promotion and primary and secondary prevention.

Numerous institutions and groups which look at the topic of healthcare (literacy) from very different angles have addressed the task. The European Union operationalises empowerment, for example by promoting the goal of harmonising different European healthcare systems by developing and setting up a health monitoring system which offers EU-wide access to reliable and current information on key healthcare topics [2].

Above and beyond this, there is a concrete need for information in patient environments where deficiencies or a lack of knowledge can have a direct impact on health status. In 1849, Virchow analysed the conditions behind a serious epidemic in Upper Silesia and recognised the link to the living conditions existing there and the lack of knowledge about healthcare (health literacy), writing in his report: “... for there can no longer be any doubt about it, that such an epidemic spread of typhoid was only possible under such living conditions as were created by poverty and lack of culture $^{1}$ in Upper Silesia. Were one to remove these conditions, I am convinced that typhoid epidemics would not return" [3]. With these words, Virchow did not merely lay the cornerstone for socio-medical thinking in medicine and the characterisation of medicine as a social science, but established an understanding in modern medicine of the importance of patients being health literate as the basis for promoting better health.

\section{Empowerment in Everyday (Medical) Work $\nabla$}

Empowering patients to take responsible decisions is a standard part of every gynaecologists' and obstetrician's work. It is reflected in the requirements for informed consent or, more generally, prepared consent.

"Informed consent" is the term used to describe the outcome of empowering patients to take decisions themselves after receiving objective factual information during counselling [4]. According to Gambrone and Reiter, [5] the acronym "PREPARED consent"2, in contrast to the more commonly used term "informed consent", emphasises the complex aspects of providing patients with a clear appreciation and understanding of facts, implications and consequences; for example, when considering the issue of informed consent prior to an obstetric delivery, information must include the benefits of the different methods of delivery, the risks and complications involved, the costs and share of costs to be borne and must take account of personal preferences. According to the recommendations of the Medical Law Task Force of the DGGG on the duty of physicians to inform and advise patients

\footnotetext{
1 Used here in the sense of "education"

${ }^{2} \mathrm{P}=$ procedure, $\mathrm{R}=$ reason, $\mathrm{E}=$ expectation, $\mathrm{P}=$ preferences, $\mathrm{A}=$ alternatives, $\mathrm{R}=$ risks, $\mathrm{E}=$ expenses, $\mathrm{D}=$ decision
} 
during prenatal care, the information given should be adapted to patient risk. According to the Ethics Commission of the International Federation of Gynaecology and Obstetrics (FIGO) [6], the goal is that after having been informed about the risks and benefits in a talk with her physician, a pregnant woman should be able to weigh the individual benefits of a preferred method against those of other methods and will be aware of her individual risk and the success of different methods. Rath and Vetter [7] rightly point out that data in the literature do not permit a precise estimation of risk profiles and that the obstetrician must nevertheless attempt to provide a qualitative and quantitative assessment. But in order to allow women to plan the birth themselves, obtaining the most precise information available is extremely important, as without this information the necessary "prepared consent" is impossible [8].

The importance of empowerment through medical concepts has also been reflected in $\S 20$ of Book V of the German Social Welfare Code (SGB V): "Primary prevention should improve the general state of health and particularly contribute to reducing healthcare inequalities arising from social inequities". Most recently, a comprehensive duty of information has been laid out in the Law to Improve the Rights of Patients, passed on February 20, 2013 [9] (mail 14.6), which includes sentences such as: "The person carrying out the treatment is obliged to inform the patient of all substantial circumstances which are important for consent." (§630e)

The clinical routines in hospitals and medical practices leave limited room for these tasks. But nevertheless, the comprehensive claim remains.

\section{Current Supply and Demand \\ $\nabla$}

At the same time, the demand for information varies intra- and inter-individually, depending on the extent of the patient's prior knowledge, situational predisposition and expectations. Greater demands may be placed on the empowerment process, which may require a social competence beyond the physician's professional/scientific skills.

Although this enumeration may appear to list items which could be considered self-evident, recent research has taught us that we may need to take a new look at familiar issues. How much and which information is good for the patient? The constraints hedged around this question are well known. The law has laid down many rules on this issue. There is a long list of verdicts which have criticised a lack of information provided to patients. Nevertheless, it is still important to ask this question and the issue requires a new debate in the near future, also in law. Given the options of genetic diagnostics and the implications for insurance law and nocebo research [10], to mention just a few, the issue concerning the right to know and the self-determined right not to know has been fuelled by debates in many different areas. Thus, the national Helmholtz cohort which is currently enrolling patients has explicitly included the "right not to know" in its codex [11]. Such aspects do not make the situation any simpler. They complicate the matter because the implications of not knowing must also be included. And so, in the debates around the Helmholtz cohort, the issue of how to deal with information in the case of new malignant growths when the patient has demanded the right not to know remains open so far.

As self-determination has become more important, the demand for better quality information, more tailored to the individual pa- tient has increased. However, no particular resources have been allocated for this in terms of reimbursement, available time or in the setting of everyday clinical practice (in all medical sectors). An acknowledgement by the system (in parallel to the demands for better health literacy) of the increased need for better communication between doctors and patients and an adaptation of the framework accordingly is still lacking.

These developments have meant that additional ways of improving health literacy are required to allow women - and others closely personally connected to her such as her partner or children, as the case may be - to decide for themselves whether and to what extent they wish to make use of what is on offer and to benefit from a range of services to meet their different and changing needs. Such additional services based on a range of different, tailored products can help patients arrive at an appropriate personal decision.

Such information is increasingly being offered at all levels of the healthcare system, both in a national and in a European or international context. In Germany, national institutions which, with differing priorities, provide information and healthcare knowledge using patient-friendly language include the Institute for Quality and Efficiency in Healthcare (IQWiG) set up by the Federal Joint Committee in accordance with $\S 139$ a SGB V [12], the German Agency for Quality in Medicine (ÄZQ), a joint organisation of the German Medical Association (BÄK) and the German National Association of Statutory Health Insurance Physicians (KBV) [13], the Federal Centre for Health Education (BZgA) [14] and the Robert Koch Institute, the central organisation of the German federal government for the monitoring and prevention of disease [15]. These federal and largely media-based sources are not equally and unrestrictedly accessible to all persons and the information provided by them needs to be complemented by regional and targeted services.

\section{The Women's Academy - Regional and Demand-Oriented $\nabla$}

The Women's Academy is an example of a regional service which has existed since 10 years at the University Gynaecological Clinic of Tübingen in cooperation with the Institute for Women's Health. The strength of this information service is not least its adaptability to specific interests and to changes in demand which occur over time. Patients are freely able to choose which elements they wish to utilise and visit.

The establishment of the Women's Academy reflects the different stages in the development of a range of services, their constituent parts and changes in demand. The Women's Academy represents a service tailored to encourage the development of health literacy in women and girls. The necessity to differentiate according to gender in the areas health, disease, health behaviour and health-promoting activities is now undisputed. The establishment of the Women's Academy was an attempt to find a way of meeting the demand to provide specific healthcare information to women which would take account of their specific stage of life and cater to their different living environment. Initiated by the University Women's Hospital and set up in 2003 with the support of the Baden-Württemberg Foundation in cooperation with the Professional Association of Gynaecologists, the community colleges (VHS) of Baden-Württemberg, the equal opportunities commissioner of the university town of Tübingen and supported by the Institute for Women's Health, the Women's Academy has 
Table 1 Topics handled by the Women's Academy, 2003-2013. The table shows the number of events on different topics presented by the Women's Academy over a period of 10 years and reflects the current interests and changes in demand for different topics.

\begin{tabular}{|c|c|c|c|c|c|c|c|c|c|c|c|}
\hline & 2003 & 2004 & 2005 & 2006 & 2007 & 2008 & 2009 & 2010 & 2011 & 2012 & 2013 \\
\hline Cancer in general & & $* * *$ & * & * & * & * & ** & $* *$ & $* * * * *$ & ** & - \\
\hline $\begin{array}{l}\text { Breast cancer and } \\
\text { general breast health }\end{array}$ & * & * & * & $* *$ & $* *$ & $* * *$ & * & $*$ & - & $* * *$ & $* * * *$ \\
\hline $\begin{array}{l}\text { Pregnancy and } \\
\text { the wish to have children }\end{array}$ & * & * & $* * *$ & * & ** & * & ** & - & - & - & - \\
\hline Menopause & * & - & * & $*$ & - & $* *$ & * & * & - & * & * \\
\hline Bladder function & - & * & $*$ & * & * & - & $*$ & $*$ & - & $*$ & - \\
\hline Sexuality & * & * & $* *$ & - & - & * & - & * & - & - & * \\
\hline Endometriosis & - & - & - & - & * & * & * & * & - & * & * \\
\hline Osteoporosis & - & - & - & * & * & - & - & * & - & * & * \\
\hline Family & * & - & - & $*$ & $*$ & - & - & - & - & - & $*$ \\
\hline Beauty ideals & - & - & * & - & - & - & * & - & - & - & \\
\hline Menstruation & * & - & - & - & - & * & - & - & - & - & - \\
\hline Other & - & - & $* *$ & $* * *$ & $* *$ & $*$ & $* *$ & $* * *$ & - & $* *$ & $*$ \\
\hline
\end{tabular}

* Events on a specific topic in each respective year

provided an open forum for information on women-specific health topics. Women, girls and other interested persons are given the opportunity to exchange experiences at lectures and during seminars and to discuss current questions and problems with affected persons and experts. The Women's Academy serves both as a forum for discussion and for the exchange of information. But the Women's Academy additionally stands out because of its outreach component.

The overview of topics listed below provides an insight into user demands over time and demonstrates the scope of the institution to adapt the range of topics on offer - borne by medical experience.

\section{Looking at topics which interest local women}

The basic premise is to ensure that the type of information offered is guided by user needs: demand shapes supply. Demand has changed in the course of 10 years ( Table 1 ); while certain topics have always been important, others have taken a break, and others have gradually become more prominent. The consistently high levels of interest in the topics breast cancer and breast health once again emphasise how central they are. As regards topics which have taken a back seat, it is possible that the women or patients have now found different ways of obtaining the information they want. For obstetric topics, for example, media-based information packages tailored to the requirements of different age groups of interested women now play a greater role. The Women's Academy is very flexible, as evidenced by the range of information on different topics, using different approaches and provided in different locations every month, which allow women to select what is appropriate for them. This aspect corresponds to the demand for self-determination. A large university Women's Hospital which does research, complemented by input from a research institute, the Institute for Women's Health, offers a guarantee for the quality of the information provided and complies with many women's need for security.

The programme has always reflected the direct interests of women living in the area, which has ensured that the events offered by the Women's Academy during its 10 year existence have always been current and the topics offered by the Academy always reflect the changing times. From the initial phase when the needs were first determined, the Academy has continued to assess the demand. Since the beginning, the Academy has benefited from unpaid voluntary work provided by lecturers and other persons involved locally when events hosted by the Women's Academy are held outside the University Hospital (see below).

\section{Topics reflect problematic areas in medicine}

and coping deficits in everyday life

The retrospective review of the 10 years' work of the Women's Academy offers an insight into the interests of women and patients insofar as the topics requested reveal what is left unsaid or not addressed in patient briefing sessions, information sessions, talks with other healthcare professionals, etc. Rising attendance figures, particularly at events for non-professionals, reflect the greater interest in and continuing demand for information and discussion. As regards opportunities to engage in discussion, the Women's Academy offers a special open discussion forum where affected women can talk about specific topics themselves. This type of interaction calls for a dialogue between diagnostic and therapeutic medicine and patients (together with their family members, many of whom also attend the events). As is the case for gynaecology and obstetrics in general, the dialogue is sometimes also aimed at men, as persons who are also involved (e.g. desire to have children), as family members supporting women in difficult situations (all areas), moreover (occasionally with a potential for conflict) as fathers-to-be in the topics pregnancy and obstetrics. Including the patient's social and family environment, if this is desired by girls and women [16], is also part of the service offered.

Records show that up to 400 participants attend the monthly events. However, the real achievement and impact go beyond mere figures, as attitudes, awareness and empowerment cannot be adequately reflected numerically.

\section{Outreach aspects of the cancer centres}

of the University Gynaecological Clinic

Since its inception, the Women's Academy has served as a forum to improve the health literacy of women/men and patients. Over time, a further aspect was added: to function as an outreach tool for the organ and cancer centres of the Women's Hospital. This aspect also developed out of the demand for such services. While the focus was initially on information provided by the Breast Centre of the University Women's Hospital, it became clear that other centres such the Pelvic Floor Centre or the Endometriosis 
Centre were increasingly interested in participating in this form of conveying health literacy and that information from these centres was increasingly being requested. A special outreach approach is required to reach women who, for varying reasons, find it difficult to access information on health, prevention or healthcare services. The inclusion of outreach aspects in acute care to facilitate access to services, empower patients to make autonomous choices and make patients aware of their choices represents a complementary structure in our healthcare system which appears to be increasingly necessary as healthcare services are becoming more and more defined by DRGs and uniform reimbursement rates for outpatient medical services (known as EBM or einheitlicher Bewertungsmaßstab in German).

To appeal to women in their specific environment, it is necessary to remove barriers by offering different means of access. For example, Health Days are held regularly and across the whole area in different regions to reach less mobile population groups or regional associations of women's groups. Special concepts have been proposed to reach women from immigrant backgrounds (to take one example of a vulnerable demographic group) with the aim of improving their integration in the German healthcare system, with events being held in more familiar surroundings, in other words, outside the University Women's Hospital.

\section{Conclusion \\ $\nabla$}

If the demand for health information catering to the needs of very different groups of women and their social environment is to be met, implementing the basic concepts "targeting" (i.e. focussing on specific groups) and "tailoring" (adapting to the respective situation and need) in healthcare promotion, and if the information provided should empower patients to make their own informed decision, then existing national, often internetbased information services need to be complemented by a form of communication tailored to the individual patient; this means, first and foremost, promoting communication between the patient and her physician (who must be given the necessary time in an appropriate framework setting within the overall healthcare system). This can be complemented by regional information services targeting different groups of women, like those offered by the Women's Academy which can respond flexibly to specific local needs.

The new challenges when developing a healthcare system based on patient self-determination in healthcare issues cannot be managed without a broad range of services to improve health literacy which take account of different needs and are provided with the necessary resources suitable to the importance of the task. The communication between physician and patient must lie at the heart of individualised medicine.

\section{Conflict of Interest \\ $\nabla$}

None.

\section{References}

1 Simoes E, Brucker SY, Beckmann MW et al. Screening for cervical cancer - minimise risks - maximise benefits. Geburtsh Frauenheilk 2013; 73 : 623-639

2 Deutscher Bundestag, Wissenschaftliche Dienste. Aktueller Begriff Europa. EU-Gesundheitspolitik. Online: http://www.bundestag.de/ dokumente/analysen/2010/EU-Gesundheitspolitik.pdf; Stand: 27.07.2013

3 Deppe HU, Regus M. Seminar: Medizin, Gesellschaft, Geschichte. Frankfurt am Main: Suhrkamp Verlag; 1975: 189

4 Vetter K, Goeckenjahn M. Ärztliche Beratung zur Geburt. Gynäkologe 2005; 7: 639-646

5 Gambrone JC, Reiter RC. Quality assessment and impairment. In: Berek JS, Adaski EY, Hillard PA, eds. Novaks Gynecology. 12th ed. Baltimore: Williams and Wilkinson; 1996

6 FIGO (International Federation of Gynecology and Obstetrics). Guidelines Regarding Informed Consent. In: Recommendations on Ethical Issues in Obstetrics and Gynecology by the FIGO Committee for the Ethical Aspects of Human Reproduction and Women's Health. London: FIGO; 2000

7 Rath W, Vetter K. Der Kaiserschnitt zwischen Selbstbestimmungsrecht der Schwangeren, Mangel an gesichertem Wissen und ärztlicher Entscheidung. Geburtsh Frauenheilk 2002; 62: 838-842

8 Simoes E, Kunz SK, Münnich R et al. Informed Consent bei der Entscheidung zum Kaiserschnitt - methodenbezogene Morbiditätsgradienten erfordern die Befähigung der Schwangeren. Geburtsh Frauenheilk 2010; 70: 732-738

9 Bundesgesetzblatt Jahrgang 2013 Teil I Nr. 9, ausgegeben zu Bonn am 25. Februar 2013

10 De la Cruz M, Hui D, Parsons HA et al. Placebo and nocebo effects in randomized double-blind clinical trials of agents for the therapy for fatigue in patients with advanced cancer. Cancer 2010; 116: 766-774

11 Helmholtz Gesellschaft. Nationale Kohorte. Ethik-Kodex. Online: http:// www.nationale-kohorte.de/ethikkodex.html; Stand: 29.07.2013

12 Institut für Qualität und Wirtschaftlichkeit im Gesundheitswesen (IQWiG). Online: http://www.gesundheitsinformation.de/startseite.2. de.html; Stand: 27.07.2013

13 Ärztliches Zentrum für Qualität in der Medizin (ÄZQ). Online: www. patienten-Information.de; Stand: 27.07.2013

14 Bundeszentrale für gesundheitliche Aufklärung. Online: http://www. bzga.de/; Stand: 27.07.2013

15 Robert Koch-Institut, Berlin. Online: www.rki.de; Stand: 27.07.2013

16 Borrmann B, Schücking B. Welche Lebensbedingungen fördern das Wohlbefinden von Säuglingsmüttern? Geburtsh Frauenheilk 2009; 69 $-\mathrm{A} 051$ 